\title{
Occurrence of most important Western honey bee (Apis mellifera) parasites (Nosema spp. and Varroa destructor) in Latvia
}

\author{
Laura Reimane $^{2 *}$, Zanda Ozoliṇa ${ }^{1,2}$, Elìna Ciekure ${ }^{1,2}$, Gunita Deksne ${ }^{1,2}$ \\ ${ }^{1}$ Institute of Food Safety, Animal Health and Environment “BIOR”, Lejupes 3, Riga LV-1076, Latvia \\ ${ }^{2}$ Faculty of Biology, University of Latvia, Jelgavas 1, Riga LV-1004, Latvia \\ ${ }^{*}$ Corresponding author, E-mail: laura.reimane@bior.lv
}

\begin{abstract}
For the last decades, trend of colony losses in Europe and worldwide is the main topic concerning honey bee health. The life span of honey bees is affected by a combination of a number of biotic and abiotic factors including infections by the mite Varroa destructor, Varroa-associated viruses, Nosema microsporidia, drought, bacteria and/or fungi. In the present study samples were collected from 570 apiaries throuhout Latvia at three times (May/June; July/August and September/October). The results showed that honey bee parasites Nosema spp. and $V$. destructor occurred in all regions of Latvia. A single species infection of Nosema ceranae was most prevalent in two seasons with low mean intensity. In contrast, mean intensity of Nosema apis was the highest overall. $V$. destructor prevalence was the highest in autumn and similarly high in most regions of country throughout the year, except in the Kurzeme region where it was the lowest.
\end{abstract}

Key words: Apis mellifera, honey bee mortality, Nosema spp., Varroa destructor.

Abbreviations: EFSA, European Food Safety Authority; EPILOBEE, a pan-European epidemiological study on honeybee colony losses; LBS, Latvian Beekeepers Society; PCR, polymerase chain reaction.

\section{Introduction}

The major part of commercial pollination services are provided by managed honey bees, making honey bees the most important commercial pollinator in Europe and worldwide (Aizen et al. 2008). Honey bee health and lifespan are affected by a number of biotic and abiotic factors, variability of bee populations and breeding conditions over the world, making it impossible to detect one main reason for the emerging colony losses trend in Europe and worldwide. The causes affecting those losses is still poorly understood, although it is likely that a combination of factors, like major infections of parasites (Nosema spp., Varroa destructor, Tropilaelaps spp., Aethina tumida etc.) viruses (chronic and acute bee paralysis virus, wing deforming virus), bacteria (American and European foulbrood), or fungi are involved (De la Rùa et al. 2009).

Nosema spp. are highly specialized, parasitic unicellular eukaryotes from the division of Microsporidia (Adl et al. 2005), a protozoa endoparasite of honey bees. Nosemosis is one of the most widespread adult bee diseases and is closely associated with significant bee mortality and therefore causing great economic losses to bee-keepers (Martín-Hernández et al. 2007; Chen, Huang 2010; OIE 2017). There are two different species invading honey bees (Apis spp.) known: Nosema apis and Nosema ceranae, both causing disorders in digestive processes (Chen et al. 2009; Fries 2010; Martín-Hernández et al. 2012; Pohorecka et al. 2014). There are epidemiological differences between the mentioned microsporidians. $N$. ceranae apparently is less host-specific as it was found in a range of hosts (Apis koschevnikovi, Apis florea, Apis dorsata) in which N. apis was never found (Chaimanee et al. 2010; Suwannapong et al. 2011; Botías et al. 2012). N. apis is strongly associated with temperate climates and seasonal patterns. In contrast, $N$. ceranae seems to not have this seasonality and climate preferences, once it infects bees throughout the year in different climates (Martín-Hernández et al. 2007; Tapaszti et al. 2009). Laboratory methods like microscopy and polymerase chain reaction (PCR) are used for detection and differentiation of Nosema spp. spores.

$V$. destructor mite is an ectoparasite affecting both the adult and developmental bee stages. $V$. destructor female mites are brown, dorsoventrally-flat, oval shaped body and it is possible to detect parasite presence with the naked eye. They suck a substantial amount of hemolymph, which leads to suppression of immune resistance and an overall shorter life span of bees due to loss of the nutrients hemolymph contains. Also, $V$. destructor acts not only as a mechanical vector for deformed wing virus, but also as a biological vector for acute bee paralysis virus, Kashmir bee virus, and Israeli acute paralysis virus, and it is associated with a 
variety of secondary diseases and virus infections (Gregory et al. 2005; De la Rùa et al. 2009; Rosenkranz et al. 2010; Genersch, Aubert 2010; Pohorecka et al. 2014;).

Studies on honey bee health related to parasites and parasite-caused diseases over the past 70 years in Latvia are fragmentary. Fundamental research was published by K. Balode (Balode 1952) and since then several authors have issued brochures (Eglïte, Šteiselis 2011; Eglite 2012) on honey bee health for the Latvian Beekeepers Society (LBS). Relatively regular monitoring data are acquired by LBS. For example, according to society's industry report of 2011 (LBS 2011): varrosis was first found in 1977 and was the most prevalent honey bee disease during three consecutive years $(87.2 \%$ in $2007 ; 87.5 \%$ in $2008 ; 85.7 \%$ in 2009). Nosemosis was the second most prevalent disease (27.9\% in $2007 ; 26.0 \%$ in $2008 ; 18.0 \%$ in 2009 ).

The aim of the present study was to estimate occurrence of the most important honey bee Apis mellifera parasites Nosema spp. and $V$. destructor in Latvia, and their geographical pattern and seasonal changes.

\section{Materials and methods}

\section{Study design}

The present study was performed within the European Commission standardized pan-European voluntary surveillance programme European Food Safety Authority (EFSA) "EPILOBEE" (2013-2015) to gather information of honey bee health and colony losses.

Geographic and climate conditions of Latvia (moist maritime, four seasons climate, with prevailing north-east winds), essentially determines development of colonies in different regions. In this study we divided Latvia in five regions based on administrative division of planning regions. In winter air temperature in Latvia changes from west to east and higher temperatures are in regions near the Baltic Sea than in continental regions. In summer coastal regions are cooled down by winds and the climate is milder than in inland regions, and also the period of vegetation is longer in the costal than in the continental part of the country (Briede 2016). The honey bee activity season can start almost month earlier in coastal than in continental regions (LBS 2011).

During 2013, samples were collected at three times (May/June 188; July/August 189 and September/October 193) from 570 apiaries (replaced with new if discontinued participation in further seasons of study) in the territory of
Latvia. Considering size of the apiary, $10 \%$ of the colonies were randomly selected but not more than 14 from each apiary. If the number of colonies in a particular apiary was less than 14, then samples were taken from other colonies. In accordance with the surveillance programme "EPILOBEE", samples for Nosema spp. detection were taken from certain proportions of the total sample volume (May/June 65\%; July/August 26\% and September/October 23\%). It was mandatory that sampling in all seasons was performed in the same colonies selected during the first visit. In the case of colony loss it was acceptable to replace it with an other colony in same apiary.

During each visit, samples from individual colonies of approximately 300 adult honey bees were collected from unsealed brood combs. Honey bees were placed in $100 \mathrm{~mL}$ plastic jars with lids, marked and transported to laboratory. Samples were stored at $4{ }^{\circ} \mathrm{C}$ until further analysis.

\section{Nosema spp. spore presence and species detection methods}

For detection of Nosema spp. spores a sub-sample of 60 bees was taken. Suspension of abdomens was made by grinding the abdominal part of bees using a mortar and pestle and adding five $\mathrm{mL}$ of distillated water. A $10 \mu \mathrm{L}$ sample from homogenous suspension was taken to fill a cover slip of haemocytometer chambers. Spores were counted at $\times 400$ magnification under light microscope and results were interpreted as number of spores $\times 10^{5}$ per bee (OIE 2017). For further tests Nosema spp. infected samples were prepared for species identification using multiplex-PCR (OIE 2017): abdominal suspension was poured through the sieve into centrifuge tubes $(15 \mathrm{~mL})$ and $5 \mathrm{~mL}$ of distilled water was added so that tube was filled to the $10 \mathrm{~mL}$ mark. Tubes were centrifuged in $800 \mathrm{~g}$ for $6 \mathrm{~min}$, then supernatant was diluted with distilled water, removed and pellets were poured into Eppendorf tubes. DNA extraction was carried out using a NucleoSpin Tissue (Macherey-Nagel, Germany) commercial kit (Cersini et al.2015). Species specific primers were used to differentiate Nosema species (Table 1).

\section{Varroa destructror mite detection method}

For detecting $V$. destructor washing procedure was used (OIE 2017): all bees in a sample were counted, placed in beaker $(0.5$ to $1.0 \mathrm{~L})$, filled up with warm $\left(40\right.$ to $\left.50{ }^{\circ} \mathrm{C}\right)$ water, and two to three drops of liquid soap was added to decrease mite ability to fixate on bee's body. The content of the baker was stirred occasionally with a glass rod for 15 to

Table 1. List of primer sets for the detection of Nosema spp. in bees by PCR (OIE Terrestrial Manual 2012)

\begin{tabular}{|c|c|c|c|}
\hline Name & Primer sequence (5’-3') & Fragment size (bp) & Specificity \\
\hline 218MITOC-FOR & 5'-CGGCGACGATGTGATATGAAA-ATATTAA-3’ & \multirow[t]{2}{*}{$218-219$} & Nosema \\
\hline 218MITOC-REV & 5’-CCCGGTCATTCTCAAACAAAA-AACCG-3` & & ceranae \\
\hline 321APIS-FOR & 5'-GGGGGCATGTCTTTGACGTACTATGTA-3' & \multirow[t]{2}{*}{321} & Nosema \\
\hline 321APIS-REV & 5'-GGGGGGCGTTTAAAATGTGAAACAAACAACTATG-3' & & apis \\
\hline
\end{tabular}


Table 2. Number of analyzed honey bee samples for detection of Varroa destructor and Nosema spp. in three different seasons and five regions of Latvia in 2013

\begin{tabular}{|c|c|c|c|c|c|c|c|c|}
\hline \multirow[t]{2}{*}{ Region } & \multicolumn{2}{|c|}{ Season 1} & \multicolumn{2}{|c|}{ Season 2} & \multicolumn{2}{|c|}{ Season 3} & \multicolumn{2}{|c|}{ Total } \\
\hline & $\begin{array}{c}\text { Varroa } \\
\text { destructor }\end{array}$ & Nosema spp. & $\begin{array}{c}\text { Varroa } \\
\text { destructor }\end{array}$ & Nosema spp. & $\begin{array}{c}\text { Varroa } \\
\text { destructor }\end{array}$ & Nosema spp. & $\begin{array}{c}\text { Varroa } \\
\text { destructor }\end{array}$ & Nosema spp. \\
\hline Kurzeme & 231 & 151 & 221 & 57 & 323 & 65 & 775 & 273 \\
\hline Latgale & 391 & 254 & 394 & 104 & 500 & 100 & 1285 & 458 \\
\hline Riga & 195 & 127 & 179 & 49 & 281 & 98 & 655 & 274 \\
\hline Vidzeme & 449 & 285 & 445 & 111 & 486 & 97 & 1380 & 493 \\
\hline Zemgale & 215 & 151 & 240 & 62 & 332 & 83 & 787 & 296 \\
\hline Total & 1481 & 968 & 1479 & 383 & 1922 & 443 & 4882 & 1794 \\
\hline
\end{tabular}

$20 \mathrm{~min}$, and then poured over a sieve $(1 \times 1 \mathrm{~mm})$ in the next glassware. Mites that were chemically and mechanically separated from bees were seen on the bottom and walls of the beaker. Bees left in the sieve were shaken over a clean glassware for one to two minutes to gather the remaining mites. Finally, all mites from a sample was counted. Results were interpreted as a number of mites per 100 bees.

\section{Data analysis}

The prevalence and mean intensity of infection was calculated as defined by Bush et al. (1997). Statistical analyses were performed using OpenEpi 3.01 (Open Source Epidemiologic Statistics for Public Health; Dean et al. 2017). The 95\% confidence intervals (95\% CI) were evaluated using the Wilson test.

\section{Results}

The In present study 4882 samples form 570 apiaries were collected from five regions of Latvia during three seasons. In all three seasons consecutively 282 apiaries took part, 179 apiaries participated in two seasons and 109 apiaries took part in one season sampling. All samples were analyzed for presence of $V$. destructor and 1794 samples were analyzed for presence of Nosema spp. (Table 2).

Overall 298 apiaries (53\%; 95\% CI: 47.6-68.0) from 558 were found to be infected with Nosema spp. Comparing by regional prevalence, in Zemgale and Kurzeme infection was most prevalent throughought year: $61.1 \%$ (95\% CI: 50.8-70.5) and 58.1\% (95\% CI: 47.6-68.0), respectively. Prevalence of Nosema spp. (from 49.3 to $51.9 \%$ ) in the other three regions was relatively similar to others. Seasonally, split Nosema spp. was more prevalent in spring (94.6\%; 95\% CI: 90.4-97.1) than in summer (38.5\%; 95\% CI: 31.7-45.7) and autumn (27.4\%; 95\% CI: 21.5-34.1). Analyzing 1794 samples for presence of Nosema spp. spores, 756 (52.8\%; 95\% CI: 50.5-55.1) samples were found to be infected. Among infected colonies, single species infection of N. apis occurred in $13.1 \%$ (95\% CI: 11.6-14.7), N. ceranae in $13.2 \%$ (95\% CI: 11.7-14.8), and 15.9\% (95\% CI: 14.3-17.7) of the colonies were infected by both Nosema species (Table 3). The highest prevalence of $N$. apis was detected in Latgale, while N. ceranae in Riga region and mixed infection in the Zemgale region (Fig. 1). Highest mean intensity for both Nosema spp. single and mixed infections was in the Zemgale region. A seasonal pattern was observed in prevalence of Nosema spp. infections: N. ceranae was more prevalent in summer and autumn seasons then in spring; in contrast, mixed infection was more prevalent in spring. Highest mean intensity for single species and mixed infections was in spring (Table 4).

$V$. destructor mite infection was detected in 474 (83\%; 95\% CI: 49.3-57.5) of 570 sampled apiaries. Over the year regional prevalence of the mite was evenly distributed among regions from $74.7 \%$ (95\% CI: 64.7-82.7) in Kurzeme to $85.8 \%$ (95\% CI: 79.6-90.4) in Vidzeme. Most prevalent $V$. destructor infection occurred in autumn (97.9\%; 95\% CI: 94.8-99.2) than in summer (87.8\%; 95\% CI: 82.4-91.8) and in spring (63.3\%; 95\% CI: 56.2-69.9). For detection of $V$. destructor, 4882 samples were analysed and 2416 (50\%; 95\% CI: 48.1-50.9) samples were found to be infected. V. destructor mite was more prevalent in autumn (71.2\%; 95\% CI: 69.2-73.2) than in summer (44.6\%; 95\% CI: 42.0-47.1) and spring (26.2\%; 95\% CI: 24.0-28.5; Table 5). The highest prevalence (53\%; 95\% CI: 50.3-55.6) of $V$. destructor was in Vidzeme region (Table 6). Mean intensity of $V$. destructor (mites per 100 bees) was highest in autumn (3.1; SD \pm 3.0$)$ comparing to spring $(1.5 ; \mathrm{SD} \pm 1.3)$ and summer $(1.7 ; \mathrm{SD}$ $\pm 1.2)$.

Table 3. Number of analyzed honey bee samples, prevalence (\%) and mean intensity (number of spores $\times 10^{5}$ per bee) of Nosema spp. single species and mixed infection in Latvia in 2013

$\begin{array}{lccc}\text { Parameter } & \text { Nosema apis } & \text { Nosema ceranae } & \text { Mixed infection } \\ \text { No. of infected samples (analyzed samples) } & 235(1794) & 236(1794) & 285(1794) \\ \text { Prevalence (Wilson CI 95\%) } & 13.1(11.6-14.7) & 13.2(11.7-14.8) & 15.9(14.3-17.7) \\ \text { Mean intensity } \pm \text { SD } & 42.7 \pm 19.8 & 8.5 \pm 7.7 & 15.3 \pm 5.3\end{array}$




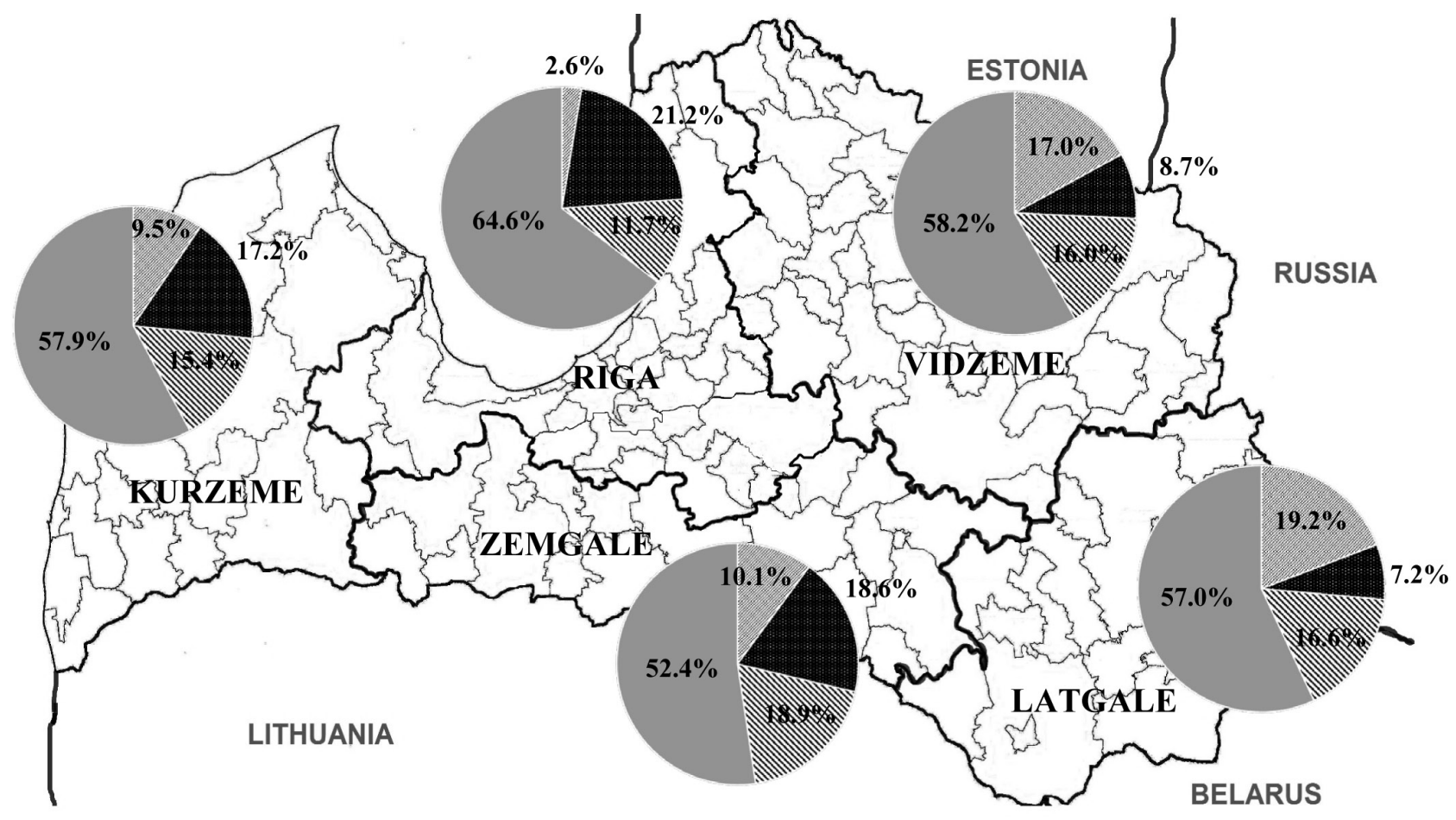

\section{Nosema apis}

Nosema ceranae

Mixed infection

Uninfected

Fig. 1. Prevalence of Nosema spp. and mixed infections in different regions of Latvia in 2013.

\section{Discussion}

The present study revealed that the total prevalence of Nosema spp. infection during 2013 was $52.8 \%$, from which most prevalent was both species mixed infection (15.9\%), which corresponds with results of a study in Poland (Michalczyk et al. 2011). In Lithuania, a four year study revealed $44 \%$ (during all study period) total prevalence of Nosema spp. infection (Blažytė-Čereškienè et al. 2016), which corresponds to the present findings, but in a five year cohort study in Germany total prevalence ranged from $22.4 \%$ (2007) to $35.4 \%$ (2008) (Gisder et al. 2010).
Comparing single and mixed infection prevalence throughout the season, $N$. apis and $N$. ceranae mixed infection in bee colonies was most prevalent in spring (25.8\%) but single species infection of $N$. ceranae was most prevalent in summer (11.2\%) and autumn (10.8\%). In different European countries such as Sweden (Paxton et al. 2007), Germany (Gisder et al. 2010), Poland (Michalczyk 2011), and Lithuania (Blažytè-Čereškienè et al. 2016) etc. Nosema spp. mixed infections also occurs, with seasonal or geographical exceptions prevailing. In Finland the infection was higher in the most southern part of the country (Forsgren, Fries 2010). Our results indicate also a seasonal

Table 4. Number of analyzed honey bee samples, prevalence (\%) and mean intensity (number of spores $\times 10^{5}$ per bee) of Nosema spp. single species and mixed infection in three different sampling seasons during 2013

\begin{tabular}{lccc} 
Sampling season & No. of infected samples (analyzed samples)/ prevalence (Wilson CI 95\%)/ mean intensity \pm SD \\
\cline { 2 - 4 } Spring & Nosema apis & Nosema ceranae & Mixed infection \\
(May/June) & $220(968)$ & $145(968)$ & $250(968)$ \\
& $22.7(20.2-25.5)$ & $15.0(12.9-17.4)$ & $25.8(23.2-28.7)$ \\
Summer & $45.2 \pm 22.5$ & $11.8 \pm 19.4$ & $16.6 \pm 33.4$ \\
(July/August) & $9(383)$ & $43(383)$ & $27(383)$ \\
& $2.4(1.2-4.4)$ & $11.2(8.4-14.8)$ & $7.1(4.9-10.1)$ \\
Autumn & $7.3 \pm 7.7$ & $2.1 \pm 1.9$ & $4.9 \pm 5.9$ \\
(September/ & $6(443)$ & $48(443)$ & $8(443)$ \\
October) & $1.4(0.6-2.9)$ & $10.8(8.3-14.1)$ & $1.8(0.9-3.5)$
\end{tabular}


Table 5. Number of analyzed honey bee samples, prevalence (\%) and mean intensity (per 100 bees) of Varroa destructor in three different sampling seasons during 2013

$\begin{array}{lccc}\text { Parameter } & \text { Spring (May/June) } & \text { Summer (July/August) } & \begin{array}{c}\text { Autumn (September/ } \\ \text { October) }\end{array} \\ \text { No. of infected samples (analyzed samples) } & 388(1481) & 659(1479) & 1369(1922) \\ \text { Prevalence (Wilson CI 95\%) } & 26.2(24.0-28.5) & 44.6(42.0-47.1) & 71.2(69.2-73.2) \\ \text { Mean intensity } \pm \text { SD } & 1.5 \pm 1.3 & 1.7 \pm 1.2 & 3.1 \pm 3.0\end{array}$

pattern of particular Nosema spp. infection prevalence. In Latvia, the $N$. apis infection peak was in spring and decreasingly low prevalence was in summer and autumn, which corresponds to results of several studies (Fries 2010; Gisder et al. 2010; Blažytė-Čereškienė et al. 2016). The seasonal prevalence of $N$. ceranae infection was highest in spring and decreased towards autumn and summer; similar results were found in studies in Lithuania and Germany (Gisder et al. 2010; Blažytė-Čereškienè et al. 2016). As Blažytè-Čereškienè and colleagues (2016) conclude, N. apis and N. ceranae seasonal variation is in agreement with characteristics of the temperate climate zone of countries with cool climate conditions.

Both disease severity and epidemiology can be influenced by interactions between the host and parasites (Paxton et al. 2007; Chen et al. 2009). Paxton (2007) suggested that $N$. ceranae is more virulent and has better adaptations to elevated temperatures, which may indicate that climate change affects spread of the pathogen (Gisder et al. 2010). In contrast, Forsgren and Fries (2013) suggesed that $N$. ceranae does not have any advantages in mixed infections and differences in infectious doses and multiplication rate between the two species are minor. The individual bee mortality (in cage experiments) caused by $N$. ceranae infections is not significantly higher than the mortality caused by N. apis (Forsgren, Fries 2010). Our study confirmed that currently in Latvia (as in Lithuania, Germany, Sweden and Finland), N. ceranae is not replacing $N$. apis, although it seems to have occurred in some regions of Europe and in the US (Chen et al. 2008; Botias et al. 2012).

In this study we found that $V$. destructor was more prevalent and reached higher mean intensity in autumn than in summer and spring. According to Rosenkranz (2010), V. destructor is closely linked to its honey bee host and lacks a free-living stage, which means that the mite is essentially linked to seasonality. In temperate climates, longlived worker bees develop in autumn (before wintering) and a substantial population of $V$. destructor mites may be present over this period. Management guidelines usually recommend Integrated Pest Management using a combination of biotechnical (drone broad removal, comb trapping, artificial swarm, and open mesh floors) and chemical (varroacides) treatment methods throughout the year against Varroa mite (LBS 2011; The Honey Bee Health Coalition 2015; The Animal and Plant Health Agency 2017), althought treatments are often applied only once a year due to more time, finance or a high level of beekeeping skills needed. Usually this treatment is performed in late autumn after the emergence of the winter bee population (Amdam et al. 2004). Therefore, we assume that the obtained data reflect the beekeepers practice of pest management in Latvia, rather than influence of other factors.

The main honey bee parasites Nosema spp. and $V$. destructor are distributed in all regions of Latvia. Single species infection of $N$. ceranae was most prevalent in two seasons, although with low mean intensity. In contrast, mean intensity of $N$. apis infection was the highest (comparing all seasons and all infections types). $V$. destructor prevalence was highest in autumn and similarly high in most regions of country (troughout the year), except in Kurzeme where it was the lowest.

\section{Acknowledgements}

The present study was implemented within the European Commission standardized pan-Europe voluntary surveillance programme EFSA "EPILOBEE". The authors would like to thank all co-workers in the Institute "BIOR" and special thanks are expressed to Rita Granta and Svetlana Cvetkova.

Table 6. Number of analyzed honey bee samples, prevalence (\%) and mean intensity (per 100 bees) of Varroa destructor in Latvia in 2013

$\begin{array}{lccc}\text { Region } & \text { No. of infected samples (analyzed samples) } & \text { Prevalence (Wilson CI 95\%) } & \text { Mean intensity } \pm \text { SD } \\ \text { Kurzeme } & 284(775) & 36.6(33.3-40.1) & 2.8 \pm 2.5 \\ \text { Latgale } & 672(1285) & 52.3(49.6-55.0) & 2.8 \pm 2.2 \\ \text { Riga } & 331(655) & 50.5(46.7-54.4) & 2.1 \pm 1.6 \\ \text { Vidzeme } & 731(1380) & 53.0(50.3-55.6) & 2.0 \pm 1.6 \\ \text { Zemgale } & 398(787) & 50.6(47.1-54.1) & 2.8 \pm 2.2 \\ \text { Total } & 2416(4882) & 49.5(48.1-50.9) & 2.5 \pm 1.3\end{array}$




\section{References}

Adl S.M., Simpson A.G.B., Lane C.E., Lukes J., Bass D., Bowser S.S., Brown M.W., Burki F., Dunthorn M., Hampl V., Heiss A., Hoppenrath M., Lara M., le Gall L., Lynn D.H., McManus H., Mitchell E.A.D., Mozley-Stanridge S.E., Parfrey L.W., Pawlowski J., Rueckert S., Shadwick L., Schoch C.L., Smirnov A., Spiegiel F.W. 2005. The new higher level classification of eukaorytes with emphasis on taxonomy of protists. J. Eukar. Microbiol. 52: 399-451.

Aizen M., Garibaldi L., Cunningham S., Klein A. 2008. Long-term global trends in crop yield and production reveal no current pollination shortage but increasing pollinator dependency. Curr. Biol. 18: 1572-1575.

Amdam G.V., Hartfelder K., Norberg K., Hagen A., Omholt S.W. 2004. Altered physiology in worker honey bees (Hymenoptera: Apidae) infested with the mite Varroa destructor (Acari: Varroidae): a factor in colony loss during overwintering? J. Econ. Entomol. 97: 741-747.

Balode K. 1952. Bee Diseases, Pests and their Protection. Latvijas PSR Zinātṇu akadēmijas izdevniecība, Rīga. 66 p. /in Latvian/

Botías C., Anderson D.L., Meana A., Garrido-Bailón E., MartínHernández R., Higes M. 2012. Further evidence of an oriental origin for Nosema ceranae (Microsporidia: Nosematidae). J. Invert. Pathol. 110: 108-113.

Botias C., Martín-Hernández R., Garrido-Bailon E., GonzálesPorto A., Martínez-Salvador A., Pilar De La Rùa A., Higes M. 2012. The growing prevalence of Nosema ceranae in honey bees in Spain, an emerging problem for the last decade. Res. Vet. Sci. 93: 150-155.

Blažytė-Čereškienė L., Skrodenytė-Arbačiauskienė V., Radžiutė S., Nedveckytė I., Būda V. 2016. Honey bee infection caused by Nosema spp. in Lithuania. J. Apicult. Sci. 60: 77-87.

Briede A. 2016. The climate of Latvia and the nature of its change. In: Kḷavinšs M., Zaļoksnis J. (eds) Climate and sustainable development. The University of Latvia Press, Riga, pp. 55-90.

Bush A. O., Lafferty K. D., Lotz J. M., Shostak A.W. 1997. Parasitology meets ecology on its own terms: Margolis et al. revisited. J. Parasitol. 83: 575-583.

Cersini A., Antognetti V., Conti R., Velletrani F., Formato G. 2015. First PCR isolation of Crithidia mellificae (Euglenozoa: Trypanosomatidae) in Apis mellifera (Hymenoptera: Apidae) in Italy. Fragm. Entomol. 47: 45-49.

Chaimanee V., Warrit N., Chantawannakul P. 2010. Infections of Nosema ceranae in four different honeybee species. J. Invertebr. Pathol. 105: 207-210.

Chen Y.P., Evans J.D., Smith I.B., Pettis J.S. 2008. Nosema ceranae is a long-present and widespread microsporidian infection of the European honey bee (Apis mellifera) in the United States. J. Invertebr. Pathol. 97: 186-188.

Chen Y.P., Evans J.D., Murphy C., Gutell R., Zuker M., GundensenRindal D., Pettis J.S. 2009. Morphological, molecular, and phylogenetic characterization of Nosema ceranae, a microsporidian parasite isolated from the European honey bee, Apis mellifera. J. Eukar. Microbiol. 56: 142-147.

Chen Y.P., Huang Z. 2010. Nosema ceranae, a newly identified pathogen of Apis mellifera in the USA and Asia. Apidologie 41: 364-374.

De la Rùa P., Jaffe R., Dall'Olio R., Muñoz I., Serrano J. 2009. Biodiversity, conservation and current threats to European honeybees. Apidologie 40: 263-284.

Dean A.G., Sullivan K.M., Soe M.M. 2017. OpenEpi: Open Source
Epidemiologic Statistics for Public Health. http://www. openepi.com./Accessed 16 September 2017/

Eglìte I. 2012. Disinfection in Apiary. Latvijas Biškopības biedrība, Riga. 32 p. /in Latvian/

Eglìte I., Šteiselis J. 2011. Restriction of Varriosis Infection in Apiaries. Latvijas Biškopības biedrība, Rīga. 52 p. /in Latvian/

Forsgren E., Fries I. 2010. Comparative virulence of Nosema ceranae and Nosema apis in individual European honey bees. Veter. Parasitol. 170: 212-217.

Forsgren E., Fries I. 2013. Temporal study of Nosema spp. in a cold climate. Environ. Microbiol. Rep. 5: 78-82.

Fries I. 2010. Nosema ceranae in European honey bees (Apis mellifera). J. Invertebr. Pathol. 103: S73-S79.

Fries I., Chauzat M.P., Chen Y.P., Doublet V., Genersch E., Gisder S., Higes M., McMahon D.P., Martin-Hernandez R., Natsopoulou M., Paxton R.J., Tanner G., Webster T.C., Williams G.R. 2013. Standard methods for Nosema research. In: Dietemann V., Ellis J.D., Neumann P. (eds) The Coloss Beebook. Vol. II: Standard methods for Apis mellifera pest and pathogen research. J. Apic. Res. 52: chapter 2.2.2.3.

Genersch, E., Aubert, M. 2010. Emerging and re-emerging viruses of the honey bee (Apis mellifera L.). Veter. Res. 41: 54 .

Gisder S., Hedtke K., Möckel N., Frielitz M.C., Linde A., Genersch E. 2010. Five-year cohort study of Nosema spp. in Germany: does climate shape virulence and assertiveness of Nosema ceranae? Appl. Environ. Microbiol. 76: 3032-3038.

Gregory P. G., Evans J. D., Rinderer T., de Guzman L. 2005. Conditional immune-gene suppression of honey bees parasitized by Varroa mites. J. Insect Sci. 5: 1-5.

Martín-Hernández R., Botías C., Bailón E.G., Martínez-Salvador A., Prieto L., Meana A., Higes M. 2012. Microsporidia infecting Apis mellifera: coexistence or competition. Is Nosema ceranae replacing Nosema apis? Environ. Microbiol. 14: 2127-2138.

Martín-Hernández R., Meana A., Prieto, L., Salvador A.M., Garrido-Bailón E., Higes M. 2007. Outcome of colonization of Apis mellifera by Nosema ceranae. Appl. Environ. Microbiol. 73: 6331-6338.

Michalczyk M., Sokół R., Szczerba-Turek A., Bancerz-Kisiel A. 2011. A comparison of the effectiveness of the microscopic method and the multiplex PCR method in identifying and discriminating the species of Nosema spp. spores in worker bees (Apis mellifera) from winter hive debris. Polish J. Vet. Sci. 14: 385-391.

OIE (World Organization for Animal Health). 2017. Nosemosis of honey bees. In: Manual of Diagnostic Tests and Vaccines for Terrestrial Animals. Version adopted by The World Assembly of Delegates of the OIE in May 2013. Chapter 2.2.4. http:// www.oie.int/fileadmin/Home/eng/Health_standards/ tahm/2.02.04_NOSEMOSIS_FINAL.pdf. /Accessed 16 September 2017/

OIE1 (World Organization for Animal Health). 2017. Varroosis of honey bees. In: Manual of Diagnostic Tests and Vaccines for Terrestrial Animals. Version adopted by The World Assembly of Delegates of the OIE in May 2008. Chapter 2.2.7. http://www.oie.int/fileadmin/Home/eng/Health_standards/ tahm/2.02.07_VARROOSIS.pdf. /Accessed 16 September 2017/

Paxton R.J., Klee J., Korpela S., Fries I. 2007. Nosema ceranae has infected Apis mellifera in Europe since at least 1998 and may be more virulent than Nosema apis. Apidologie 38: 558-565.

Pohorecka K., Bober A., Skubida M., Zdańska D., Trój K. 2014. A Comparative study of environmental conditions, bee 
management and the epidemiological situation in apiaries varying in the level of colony losses. J. Apicult. Sci. 58: 107-132.

Rosenkranz P., Aumeier P., Ziegelmann B. 2010. Biology and control of Varroa destructor. J. Invertebr. Pathol. 103: 96-119.

Suwannapong G., Yemor T., Boonpakdee C., Benbow M.E. 2011. Nosema ceranae, a new parasite in Thai honeybees. J. Invertebr. Pathol. 106: 236-241.

Tapaszti Z., Forgách P., Kövágó C., Békési L., Bakonyi T., Rusvai M. 2009. First detection and dominance of Nosema ceranae in Hungarian honeybee colonies. Acta Vet. Hung. 57: 383-388.
The Animal and Plant Health Agency. 2017. Managing Varroa. In: The National Bee Unit. http://www.nationalbeeunit.com/ downloadDocument.cfm?id=16. /Accessed 30 September 2017/

The Honey Bee Health Coalition. 2015. A guide to effective Varroa sampling and control. In: Tools for Varroa management. https://honeybeehealthcoalition.org/wp-content/ uploads/2015/08/HBHC-Guide_Varroa-Interactive-PDF.pdf. /Accessed 30 September 2017/ 